\title{
Work-family Role Conflicts among Malaysian Female Primary School Teachers
}

\author{
Lawal Abdul Faragai \\ School of Education College of Arts and \\ Sciences \\ Universiti Utara Malaysia \\ Sintok, Malaysia \\ lawalfaragai@yahoo.com
}

\author{
Fahainis Bt. MohdYusof \\ School of Education College of Arts and \\ Sciences \\ Universiti Utara Malaysia \\ Sintok, Malaysia
}

\author{
Lim Chong Ewe \\ School of Education College of Arts and \\ Sciences \\ Universiti Utara Malaysia \\ Sintok, Malaysia \\ limce89@gmail.com
}

\begin{abstract}
The objective of this research is geared towards sharing knowledge and plan to investigate whether the female primary school teachers in Malaysia are experiencing workfamily roles conflict or not. Researchers have realized that studies on female primary school teacher's work-family role conflicts experience have been neglected. Hence, the concern of this study will also discuss the relevant theories of work-family role conflicts from the perspectives of the famous scholars. Moreover, the study will similarly deliberate on the various empirical researches related to the current investigation. In addition, a proposed method and techniques of conducting this research will be discussed for the successful investigation of the study. In a nutshell, the relevance of this study would be helpful to the female primary teachers in Malaysia and others, the school head teachers, couples of career women, ministries of Education, researchers and the general populace
\end{abstract}

Keywords-Work-family conflict; role conflicts; female primary school teachers;

\section{INTRODUCTION}

Many researches have been conducted regarding the issue of roles conflicts among dual-career workers in various organizations. Little wonder then, researchers have failed to consider the grassroots level of education, which is the primary education, it is the solid foundation of all field of education. But they focus their attention on other levels of education and another field of human endeavours as the most vital area to conduct research upon. The world at large is agitating for the Global education for all as the current and general phenomenon. In fact, some researchers have witnessed the running away of many able male primary school teachers to other professions for better pay and prestige. Leaving female primary school teachers with their full and dedicated supports to educate our children. The data extracted by UNESCO EFA [1] on global overview (2011), female primary school teachers were $63 \%$ globally. The existing scarcity of male primary school teachers was the byproduct of an economic factor which necessitated the male teachers to change from teaching to other better profession [2]. Primary school teachers are responsible to teach our younger children with basic literacy, numeracy and many more subjects expecting them to become respected and valuable members of our societies. This study will like to investigate whether female primary school teachers in Malaysia are experiencing work-family role conflicts as others do. According to the World Population Review Report [3], Malaysian population is estimated to about $31,164,177$. The country is located on the continent of Asia to the south-Eastern. The area is bordered by Thailand with estimated $330,803 \mathrm{~km}$. The country has bordered with Indonesia and Brunei. The Malaysian country has a sea frontiers with Singapore, Vietnam, and Philippines. The Malaysia National Review Education for all [4] showed the percentages male primary teachers were less than the female primary school teachers. Furthermore, the Malaysian Federal Ministry of Education [5] presented a total figure of primary school teachers is 229,050 . While the total number of 2,742,989 million pupils are attending public primary schools.

In an attempt to investigate work-family roles conflict among Malaysian female primary school teachers, there is need to focus on the previous research conducted regarding the issue of work-family role conflict. Relevant research conducted in East Malaysia [6] view that research of such kind was widely found in the western countries but very rare in Asia and indeed in Malaysia. This particular study focus on the theory of role which remains the popular guiding theory regarding the issue of role conflicts. The popular theory of Kahn et al. [7] deliberate that role conflict is regarded as the happening together of two or more roles that at the same time become irreconcilable to each other. Moreover, there is another prevalent theory known as spill-over which Pleck [8] regards the spill-over theory as the appropriate theory while investigating work-family role conflict. Furthermore, Staines, [9], [10], [11], [12], [13], [14]. This really shows that work and family domain is very crucial to every worker especially married men and women [15]. It was further indicated that the spill-over of certain behaviours, characters, manners and 
exhaustion incited from one domain can spill-over to another domain [16]. Work-family conflict among teachers was a very dynamic issue to investigate, in order to find out whether the precursor and outcomes are similar to other professions [17]. Indeed, many researchers did not consider teachers as a rich target to investigate the level of their work-family conflict and there is a harmonious relationship between work and family in the teaching profession. But in the real sense, other researchers have confirmed that teachers do experience work-family role conflict which the related empirical research would provide us with vital facts to the matter under study.

\section{WORK-FAMILY CONFLICT THEORY}

The work-family conflict theory is another prominent theory postulated by Greenhaus and Beutell [18]. Scholars who are more concern in studying work-family conflict usually tend to acknowledge the three sources of work-family conflict with their models of work-family role pressure incompatibility. The theory has indeed, become very famous and applicable to many types of research investigating workers. The proponents of this theory consider dual-roles conflict as work-family conflict as well. This is the situation whereby a dual-career worker's anticipated responsibilities from the family and work domain usually happens to be incompatible. The three sources of work-family conflict are as follows; Time-Based Conflict, Strain-Based Conflict, and Behavior-Based Conflict. The Time-Based Conflict is the type of conflict that workers experience clashes of time between work schedules and family responsibilities, of course, this what makes work to experience confusing. The Strain-Based Conflict is another situation whereby the workers experience excessive stress in trying to play two responsibilities at the same time or one obligation supersede other response from the other domain. Behaviour-Based Conflict is another source of work-family conflict a condition where a role performer behaviour was pressurized from a particular domain may likely to control himself or herself leading to a conflicting condition. The pressurizedbehaviour is spill-over to either home or work domain.

\section{PROPOSED METHODOLOGY}

In this study, a qualitative design will be applied to investigate work-family role conflicts among Malaysian female primary school teachers using a case study of the particular area especially in Northern Malaysia where the researcher could be access to contact appropriate participants of the study. Also, interview techniques will be used among appropriate participants who are willing to provide related answers to the interview questions. A case study is often been used in qualitative methodology more especially educational research, and there is no general agreement concerning the implementation of case study design; as a result, its progress becomes obstructed [19]. Additionally, case study research is related to the study of an event in a given circumstances, in a such a way that the study produces a result on how the event happen in a given time [2o].

\section{DISCUSSIONS}

Numerous researchers have conducted researches on work-family role conflicts in many areas of their scope. This particular study is a conceptual attempt, as a steppingstone toward proposing the empirical work regarding the second paper. A conducted research by, Achour et al. [21]) revealed that a maximum number of female lecturers in Malaysian Universities experience roles conflict from their work domain to their homes respectively. In addition, the results of findings revealed that the Malaysian female academicians wereexperiencing a high rate of absenteeism, job dissatisfaction, and family dissatisfaction as a result of the work-family role conflicts. The research of Christiana [22] found that the dual responsibilities of female academicians in the Nigerian south-western Universities experience multiple roles conflict in their academic and home domain. Habaci [23] research has discovered that both male and female primary school teachers in Turkish province experience role conflict. The researcher also discovered some remedies to minimize roles conflict and issues of gender differences among teachers. Research conducted in Kenya, discover $52.9 \%$ percentages regard female principal pressures was as a result of multiple role conflicts, lack of professional exposure, lack of confidentiality. Consequently, the outstanding $47.1 \%$ was other issues that were not deliberated but would be studied in future research [24]. It was however found that the increasing number of married female teachers in Malaysia is becoming multifaceted due to multiple role conflicts as wives, mothers, and workers. These dual roles usually affect the entire lives of the female primary school teachers and their family members as well [25]. Another study [26] revealed that during the period 2008 to 2011 quite number of teachers in Malaysia were decided to seek for retirement and resignation due to the outcome of job displeasure. The higher rate of teachers usually leaving their job could be as a result of dissatisfaction with the job [27]. On the contrary, some studies have found that there is a low level of job stress among the married women in east Malaysia confirming that marital status has no influence on work-family conflict. Those who are not married experience high level of job stress, while those with their spouse share their problems and proper solution to it [6Indeed, the salary of teachers in Malaysia was sufficient for the teacher to remain in the service for life [4]. Even with this, yet female primary school teachers in Malaysia are experiencing work-family role conflicts. Hopefully, with the growing research on the work and family related issues on teachers things will be normalized.

\section{CONCLUSION}

In conclusion, investigation on work-family role conflicts among Malaysian female primary school teachers can be regarded as crucial and unique, because many researchers focus their attention on other areas while this is the solid foundation of every country level of education. Also, themajority of primary school teachers are female teachers more especially in Malaysia. Conducting such research could be a relevance to female primary teachers, their male partners, head teachers, researchers and the ministry of education. This study will act as a pedestal to further investigation in the area of work-family Conflict as well as to gain knowledge which 
will spur teachers and other workers having the experiences on the effects of role conflicts in their life well-being.

\section{ACKNOWLEDGEMENT}

This research was supported by Universiti Utara Malaysia.

\section{REFERENCES}

[1] UNESCO EFA. "The global overview on the percentage of female primary school teachers". Global Monitoring Report Author, Paris. (2013/2014).

[2] Medford L, Knorr R, Cook M. Men Missing from the PK-12 Classroom-A Discussion of Research-Based Explanations. SRATE Journal. 2013;22(2):14-21

[3] Retrieved from http://worldpopulationreview.com/countries/ 2017.

[4] Malaysia Education for All 2015 National Review.

[5] Ministry of Education Malaysia. "Malaysia Education Blueprint 20132025" Putrajaya: Ministry of Education Malaysia (2013a).

[6] Jamadin N, Mohamad S, Syarkawi Z, Noordin F. Work-family conflict and stress: evidence from Malaysia. Journal of Economics, Business and Management. $2015 \mathrm{Feb}$;3(2):309-12.

[7] Kahn RL, Wolfe DM, Quinn RP, Snoek JD, Rosenthal RA. Organizational stress: Studies in role conflict and ambiguity 1964.

[8] Pleck JH. The work-family role system. Social problems. 1977 Apr $1 ; 24(4): 417-27$.

[9] Staines GL. Spillover versus compensation: A review of the literature on the relationship between work and nonwork. Human relations. 1980 Feb;33(2):111-29.

[10] Lambert SJ. Processes linking work and family: A critical review and research agenda. Human relations. 1990 Mar;43(3):239-57.

[11] Young L, Kleiner BH. Work and family: Issues for the 1990s. Women in Management Review. 1992 May 1;7(5).

[12] Williams KJ, Alliger GM. Role stressors, mood spillover, and perceptions of work-family conflict in employed parents. Academy of Management Journal. 1994 Aug 1;37(4):837-68.
[13] Doby VJ, Caplan RD. Organizational stress as a threat to reputation: Effects on anxiety at work and at home. Academy of Management Journal. 1995 Aug 1;38(4):1105-23.

[14] Grzywacz JG, Almeida DM, McDonald DA. Work-family spillover and daily reports of work and family stress in the adult labour force. Family relations. 2002 Jan 1;51(1):28-36.

[15] Greenhaus JH, Parasuraman S, Granrose CS, Rabinowitz S, Beutell NJ. Sources of work-family conflict among two-career couples. Journal of Vocational Behavior. 1989 Apr 30;34(2):133-53.

[16] Hammer LB, Allen E, Grigsby TD. Work-family conflict in dual-earner couples: Within-individual and crossover effects of work and family. Journal of vocational behaviour. 1997 Apr 1;50(2):185-203.

[17] Cinamon RG, Rich Y. Work-family conflict among female teachers. Teaching and teacher education. 2005 May 31;21(4):365-78.

[18] Greenhaus JH, Beutell NJ. Sources of conflict between work and family roles. Academy of management review. 1985 Jan 1;10(1):76-88.

[19] Yazan B. Three approaches to case study methods in education: Yin, Merriam, and Stake. The Qualitative Report. 2015;20(2):134-52.

[20] Farquhar JD. Case study research for business. Sage; 2012 Feb 21.

[21] Achour M, Grine F, RoslanMohdNor M. Work-family conflict and coping strategies: Qualitative study of Muslim female academicians in Malaysia. Mental Health, Religion \& Culture. 2014 Nov 26;17(10):1002-14.

[22] Christiana OO. Work-Family role conflict among academic women in Nigerian Public Universities. Osun State, Nigeria: International Academic Conference Proceedings 2013.

[23] Habaci I. Investigation of primary class teachers' conflict approaches by gender. Educational Research and Reviews. 2015 Jun 23;10(12):1702

[24] Juma, K. A., Simatwa, M. W., Ayodo, M.A. Factors Influencing Stress among Public Secondary School Female Principals in Kenya: Case Study of Rachuonyo North and Homa Bay Sub-Countries. International Research Journals. 7 (2), 041-054 (2016).

[25] Ismail Z, Nordin MS. Teachers' Work-Family Conflict in Malaysia: Scale Validation. International Journal of Business and Social Research. 2012;2(5):122-31.

[26] Fung NS, Ahmad A, Omar Z. Work-Family Enrichment: It's Mediating Role in the Relationships between Dispositional Factors and Job Satisfaction. International Journal of Academic Research in Business and Social Sciences. 2012 Nov 1;2(11):73.

[27] Ministry of Education, Malaysia, 2012. Preliminary Report Malaysia Education Blueprint 2013-2025. Malaysia: Human Resource Management Division, Ministry of Education. 